\title{
LAMMASTALOUDEN KANNATTAVUUDESTA HELSINGIN YLIOPISTON MALMINKARTANON TILALLA
}

\author{
VILJO RYYNÄNEN \\ Helsingin yliopiston maanviljelystalouden laitos, Viikki
}

Saapunut 1. 2. 1969

Vuonna 1962 aloitettiin Malminkartanoon kuuluvalla Honkasuon pientilalla lampaanhoidon taloudellisuutta selvittelevä koe. Keskeisimpiä tavoitteita on ollut tarkkailla lampaanhoidon taloudellisia ja teknillisiä mahdollisuuksia olosuhteissa, joissa tilan työvoima hoitaa lampaat sivutoimenaan. Samalla on tarkkailtu lampaiden rehunkulutusta. Laidunrehun kulutusta ei ole voitu tarkkailla vaan se on laskettu saatavissa olevien normien mukaan. Kun lampaiden laiduntaminen on tapahtunut voimaperäisesti viljellyllä peltolaitumella, on voitu kiinnittää huomiota myös laidunrehun tuottamisen tekniikkaan ja laidunten sadon talteen ottamiseen.

Vuonna 1962 syksyllä hankittiin tilalle 20 noin kuuden kuukauden ikäistä uuhikaritsaa ja pässi. Hankitut lampaat ovat suomalaisia maatiaislampaita. Tätä eläinkantaa on lisätty niin, että katras oli talvella 1966/67 ensimmäisen kerran suunnitellun suuruinen (noin 50 uuhta).

\section{Ruokinta}

Lampaiden käyttämä rehu on ollut pääasiallisesti karkeata rehua. Kolmen viimeisen vuoden aikana käytetyt rehut ja eri rehujen osuus käytetystä ry-määrästä käyvät ilmi taulukosta 1.

Uuhet karitsoineen, pässi ja katraan uusimiseen tarvittava lisäkasvu on käsitelty tässä yhtenä kokonaisuutena. Kun kokonaisrehumäärä on jaettu karitsoineitten uuhien luvulla, on saatu rehunkulutus yhtä uuhta kohti. Ennen jakoa on kokonaisrehumäärästä vähennetty niitten uuhien rehunkulutus, jotka eivät ole karitsoineet. Myös katraan lisäykseen käytettyjen lampaitten rehunkulutus 5 kuukauden ikäisestä aikuiseksi on vähennetty ennen jakoa kokonaisrehumäärästä. Lisäkasvuun ja elatukseen käytetty rehumäärä on laskettu Gustafsson ja SJöBergin (1966) mukaan. Laidunrehun kulutus on arvioitu ottaen huomioon eri ikäisten lampaiden elatus- ja tuotantorehun tarve laidunpäivää kohti. 
Taulukko 1. Lampaiden käyttämät rehut ja niiden suhteellinen osuus ry-määrästä.

Table 1. Fodder consumed by sheep and proportion of fodder in the total of fodder units (f.u.).

\begin{tabular}{|c|c|c|c|c|c|c|}
\hline \multirow{2}{*}{$\begin{array}{l}\text { Rehu } \\
\text { Fodder }\end{array}$} & \multicolumn{2}{|c|}{1965} & \multicolumn{2}{|c|}{1966} & \multicolumn{2}{|c|}{1967} \\
\hline & $\begin{array}{r}\text { ry } \\
f . u .\end{array}$ & $\%$ & $\begin{array}{l}\text { ry } \\
f . u .\end{array}$ & $\%$ & $\begin{array}{l}\text { ry } \\
f . u .\end{array}$ & $\%$ \\
\hline Tuku-rehu & 259 & 1.4 & - & - & 335 & 1.2 \\
\hline Tuku-concentrate & & & & & & \\
\hline $\begin{array}{l}\text { Kaura } \\
\text { Oats }\end{array}$ & 1519 & 8.1 & 3322 & 14.1 & 3689 & 12.9 \\
\hline Heinä & 6056 & 32.4 & 7460 & 31.6 & 9276 & 32.6 \\
\hline Hay & & & & & & \\
\hline $\begin{array}{l}\text { Säilörehu } \\
\text { Silage }\end{array}$ & 1207 & 6.5 & 2707 & 11.4 & 4133 & 14.5 \\
\hline Oljet, nadan & 943 & 5.1 & 543 & 2.3 & 171 & 0.6 \\
\hline $\begin{array}{l}\text { Straw } \\
\text { Laidun } \\
\text { Pasture }\end{array}$ & 8700 & $\left.46.5^{1}\right)$ & 9600 & $\left.40.6^{1}\right)$ & 10900 & 38.2 \\
\hline $\begin{array}{l}\text { Yhteensä, Total } \\
\text { ry/uuhi, f.u.|ewe }\end{array}$ & $\begin{array}{r}18684 \\
394\end{array}$ & 100.0 & $\begin{array}{r}23632 \\
454\end{array}$ & 100.0 & $\begin{array}{r}28504 \\
470\end{array}$ & 100.0 \\
\hline
\end{tabular}

1) Tähän sisältyy myös syksyllä laitumelle annettu rehukaali. Including marrow kale given at pasture in the autumn.

Vuonna 1965 talvirehun kulutus uuhta kohti jäi selvästi pienemmäksi kuin seuraavina vuosina. Tähän lienee vaikuttanut lähinnä rehujen hyvä laatu. Talvella 1966/67 heinä on ollut laadultaan keskitasoa heikompaa. Tämä on aiheuttanut rehun kulutuksen lisääntymistä. Myös talviruokintakauden pituus on vaihdellut huomattavasti aiheuttaen variaatiota talvirehun kulutukseen. Keskimääräinen rehunkulutus vuosina 1965-1967 oli Honkasuon katraassa 440 ry uuhta kohti. GuSTAFsson ja SJöBERG (1966) laskevat ruotsalaisen maatiaislampaan käyttävän noin 470 ry silloin, kun se kasvattaa 1.7 karitsaa 5 kuukauden ikäiseksi ja karitsain teuraspaino on noin $22 \mathrm{~kg}$. Tämä vastaa verraten hyvin Honkasuon tulosta. Honkasuon uuhilla oli tosin 1.8 karitsaa, mutta karitsain teuraspaino oli 4.5 kuukauden ikäisinä keskimäärin $17.5 \mathrm{~kg}$. NIELSEN (1960) on selostanut eräillä lammasroduilla Tanskassa 1953 - 55 suoritettuja kokeita. Näiden tulosten mukaan käyttivät Shropshire lampaat 466 ry. Karitsain teuraspaino oli $18 \mathrm{~kg}$. Karitsaluku oli koeryhmässä 1.6.

Lampaiden laiduntaminen on tapahtunut voimaperäisessä viljelyssä olevilla peltolaitumilla. Laitumista on ollut 3/4 turvepintaista maata ja 1/3 kivennäismaata. Lampaat näyttävät selvästi vieroksuvan turvealueiden ruohoa. Ne syövät ensiksi kivennäismaan laitumen paljaaksi ja vasta tämän jälkeen käyttävät turvealueen ruohoa. Erityisen halukkaasti lampaat ovat syöneet peltojen liepeillä olevia vähäisiä, luonnonvaraisia laitumia.

Kuviosta 1 käy ilmi uuhen, jolla on kaksi huhtikuun puolivälissä syntynyttä karitsaa, päivittäinen rehun tarve touko-syyskuun aikana (INKOvAARA 1964). Samaan kuvioon on piirretty laitumen, jonka kokonaissato on yhtä suuri kuin emän ja karitsoitten laidunrehun tarve, päivittäinen sato samana aikana (HuokunA 1964). Kaavamaisuudestaan huolimatta kuvio ilmaisee sen epäsuhteen, joka vallitsee laitumen luonnollisen tuoton ja katraan lai- 


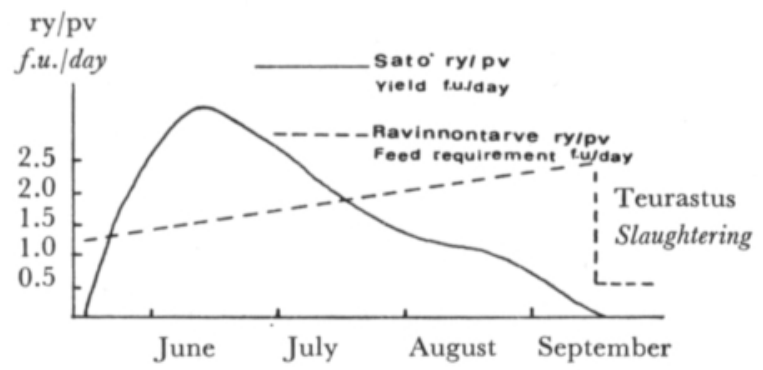

Kuvio 1. Laidunrehun päivittäinen lisäkasvu sekä uuhen ja kahden 15. 4. syntyneen karitsan ravinnontarve päivittäin laidunkautena.

Fig. 1. Daily growth of pasture forage and daily feed requirement of ewe and 2 lambs born April 15 during grazing season.

dunrehun tarpeen välillä. Mitä myöhäisemmäksi karitsoiminen siirtyy sitä suurempi osa laitumista on korjattava säilörehuksi ja sitä enemmän on varauduttava tuottamaan laidunja tuorerehua muilla menetelmillä.

Laidunrehun määrää elo- ja vielä syyskuussakin on Honkasuon tilalla lisätty pitämällä laidunalaa niin runsaasti, että kesäkuussa on voitu valmistaa huomattava määrä säilörehua. Toinen sato on korjattu laiduntamalla. Tästä on ollut seurauksena laidunalan lisääntyminen ja vastaava aitauskustannusten nousu. Koko laitumen sadon on arvioitu muodostuvan noin $35 \%$ suuremmaksi kuin laskettu laidunrehun tarve. Lisäksi on kasvatettu rehukaalia $0.5-1.0$ hehtaarin alalla, josta osa on tehty säilörehuksi.

Lisärehun tuottamisesta huolimatta laidunrehua ja tuorerehua on ollut kuivimpina vuosina liian vähän elokuun aikana. Kun lampaanlihan hinta on tällöin ollut korkein, on huomattava osa teurastettavista karitsoista myyty jo elokuun alussa.

\section{Karitsatuotos}

Suomalaisen maatiaislampaan hyvä sikiävyys on tullut tutkimuksen kohteena olleessa katraassa selvästi ilmi (taulukot 2 ja 3). Vuosina 1963 ja 1964, jolloin ensikertaa karitsoineiden osuus katraasta oli suhteellisesti suurin, syntyneiden luku oli huomattavasti pienempi kuin vuosina 1965 - 67, jolloin uuhien keski-ikä oli lisääntynyt.

Kuolleitten karitsain luku vuosina 1965 - 67 on ollut huomattavan suuri. Alle 2-vuotiaitten uuhien karitsoista on kuollut $30 \%$ ja yli 2-vuotiaitten $20 \%$. Kolmos- ja neloskaritsoista on kuollut keskimäärin 0.8 karitsaa synnytystä kohti, kun ykkös- ja kaksoskaritsoista on kuollut 0.3 . Kuolleitten joukkoon on luettu myös kuolleina syntyneet, jos ne ovat olleet muutoin täysin kehittyneitä. Kuolemantapauksista on sattunut $69 \%$ ensimmäisen kolmen vuorokauden aikana. Tämän jälkeen kuolleista (22 karitsaa) pääasiallinen osa on keväällä 1966 kuolleita. Karitsat saivat tuolloin ilmeisesti bakteeritartunnan, joka aiheutti 16 karitsan kuoleman.

Sekä liha- että villatuotoksen kannalta on merkitystä lähinnä teurasiän saavuttaneilla karitsoilla. Varsinaisesti tämä luku yhdessä karitsain painon kanssa ilmaisee karitsatuotoksen. Teurastettujen karitsain keski-ikä Honkasuon katraassa on ollut vähän yli 4.5 kuukautta. Näiden luku emää kohti on kolmen viimeisen vuoden keskiarvona 1.8. Ensimmäis- 
Taulukko 2. Elävänä syntyneiden, kuolleiden ja 5 kuukauden ikäisten karitsoiden luku keskimäärin uuhta kohti vuosina $1963-67$.

Table 2. Average number of liveborn, dead and 5 months old lambs per ewe in 1963-1967.

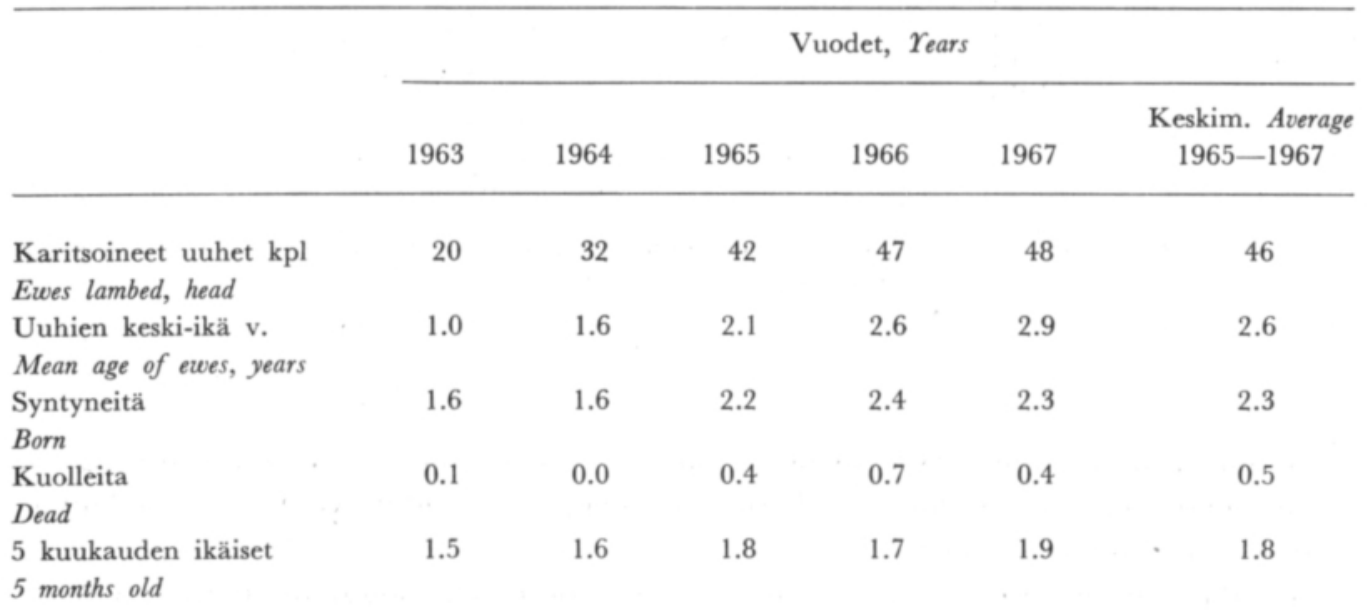

Taulukko 3. Eri ikäisille uuhille syntyneiden ja 5 kuukauden ikäisten karitsain luku vuosina 1965 - 67. Table 3. Number of lambs born to ewes of different ages and number of 5 months old lambs in 1965-1967.

\begin{tabular}{llccccc}
\hline & \multicolumn{5}{c}{ Uuhien ikävuotta, Age of ewes, years } \\
& 1 & 2 & 3 & 4 & 5 \\
\hline $\begin{array}{l}\text { Syntyneitä } \\
\text { Born }\end{array}$ & 1.6 & 2.3 & 2.7 & 2.9 & 3.0 \\
$\begin{array}{l}5 \text { kk ikäisiä } \\
5 \text { months old } \\
\text { Uuhien luku } \\
\text { Number of ewes }\end{array}$ & 1.1 & 1.7 & 2.3 & 2.3 & 2.4 \\
\hline
\end{tabular}

ten vuosien luvut eivät vastaa normaalia lammastaloutta, koska uuhet olivat tällöin hyvin nuoria (taulukko 2). Karitsaluvun on todettu selvästi lisääntyvän aina neljänteen ja viidenteen karitsoimiskertaan saakka (Majjala 1967, Nedkvitne 1966). Tutkimuksen kohteena olleen katraan keskimääräinen karitsaluku ylittää huomattavasti esim. ruotsalaisen maatiaislampaan keskimääräisen karitsaluvun 1.4 (JoHnsson et al. 1960). Lampaiden tuotannontarkkailun mukaan on yli 2-vuotiaiden uuhien keskimääräinen karitsaluku ollut suomalaisella maatiaislampaalla 2.4 syntynyttä ja 2.1 eloon jäänyttä (Lammastalous 1962 67). Tuotannontarkkailutilojen karitsaluku ylittää Honkasuon tilalla keskimäärin saavutetut tulokset. Syntyneiden luku on lähes sama, mutta 5 kuukauden ikäisten karitsain luku on ollut tutkimustilalla 0.3 karitsaa uuhta kohti pienempi. Jos otetaan huomioon ainoastaan yli 2-vuotiaana karitsoineet uuhet, kuten tarkkailukatraissa tehdään, tulee karitsaluvuksi Honkasuon katraassa 2.7 syntynyttä ja 2.2 teurasiän $(4.5 \mathrm{kk})$ saavuttanutta.

\section{Lihatuotos}

Karitsoista on käytetty osa katraan lisäämiseen ja osa on myyty elävänä. Lihatuotoksen selvittämiseksi on karitsoista kasvatettu teuraiksi vuosina 1965-67 yhteensä 140. Teuraaksi 
tarkoitetut karitsat on myyty noin 4.5 kuukauden ikäisinä. Syynä tähän on ollut lampaanlihan voimakas kysyntä ja hyvä hinta elokuussa sekä laidunrehun puute. Lihatuotosta olisi ilmeisesti voitu lisätä $2-3 \mathrm{~kg}$ karitsaa kohti, jos ne olisi myyty vasta syyskuun lopulla. Kun laidunrehun kasvu on jo heinäkuun lopulla ja elokuussa ollut vähäinen, olisi lampaiden rehuntarpeen tyydyttämiseksi täytynyt kasvattaa huomattava määrä vihantarehua tai käyttää talvirehua. Kokeen tässä vaiheessa vihantarehun tuottaminen ei ollut riittävää eikä talvirehun näin varhaista käyttöä pidetty kokeen kannalta tarkoituksenmukaisena.

Gustafsson ja FröBERG (1966) esittävät 5 kuukauden ikäisten ruotsalaisen maatiaislampaan karitsoiden teuraspainoksi $13.6 \mathrm{~kg}$. Kun 5 kuukauden ikäisten karitsain keskimääräinen luku Ruotsin tarkkailukatraissa on ollut 1.4, on lihatuotos uuhta kohti ollut $19.0 \mathrm{~kg}$.

Taulukko 4. Karitsoiden keskimääräinen teuraspaino ja lihatuotos uuhta kohti vuosina 1965 - 1967. Table 4. Average carcass weight of lambs and meat output per ewe in 1965-1967.

\begin{tabular}{lcc}
\hline & $\begin{array}{c}\text { Karitsain teuraspaino kg } \\
\text { Carcass weight of lambs }\end{array}$ & $\begin{array}{c}\text { Lihatuotos kg/unhi } \\
\text { Meat output, kg/ewe }\end{array}$ \\
\hline & & \\
1965 & 9.4 & 17.0 \\
1966 & 10.4 & 18.0 \\
1967 & 9.2 & 17.6 \\
\hline Keskim. Average & 9.7 & 17.5
\end{tabular}

Maamme lampaiden tuotannontarkkailutiloilla karitsatuotos lasketaan yli 2 vuotiailta uuhilta. Näillä tiloilla karitsan keskimääräinen elopaino on ollut $29 \mathrm{~kg}$ ja lihatuotos (teuras \% 40) $11.6 \mathrm{~kg}$ (Lampaiden tuotannontarkkailu 1962 ja 1967). Verratessa Honkasuon tilalla saavutettuja tuloksia edellä esitettyihin on otettava huomioon, että Honkasuon tilan uuhet ovat olleet hyvin nuoria. Tästä on aiheutunut karitsaluvun jäämistä pienemmäksi kuin maamme tarkkailutiloilla. Honkasuon tilan lammaskatrasta on lisätty ja lisäykseen on käytetty parhaita karitsoita. Teuraiksi ovat jääneet heikoimmat uuhikaritsat ja osa pässikaritsoista. Myös tästä syystä lihatuotos lienee jäänyt pienemmäksi kuin siinä tapauksessa, että uusimista lukuunottamatta kaikki karitsat olisi teurastettu. Honkasuon tulosta arvosteltaessa on syytä ottaa huomioon, ettei lampaita ole erityisemmin vaalittu kuten pienissä katraissa usein tapahtuu. Heikkoja karitsoita ei ole autettu elämään ruokkimalla niitä erikseen maidolla tai muulla lisärehulla. Koe on suoritettu ikäänkuin katras olisi yhden henkilön sivutöinä hoidettavana. Tämän vuoksi tulosta voidaan verrata lähinnä suurehkojen katraitten keskituotokseen.

Koe osoittaa, että talouslampoloissa voi keskimääräistä tasoa oleva suomalainen lammas tuottaa lihaa yhtä uuhta kohti $20-25$ kg vuodessa kuiva heinä-, painorehu-, kauraja laidunruokinnalla edellyttäen, että karitsat kasvatetaan noin 5 kuukauden ikäisiksi. Uuhien ja karitsain vaaliminen ja erikoishoito voidaan jättää kokonaan pois.

\section{Villatuotos}

Emät on keritty kaksi kertaa vuodessa. Mikäli karitsa on jätetty kasvamaan, on se keritty laidunkauden päätyttyä. Teurastettuja karitsoita ei ole keritty. Karitsain ja pässin villatuotos on laskettu yhden vuoden koepunnituksen mukaan (Taulukko 5). 
Taulukko 5. Villatuotos vuosina 1963-67.

Table 5. Wool output in 1963-67.

\begin{tabular}{|c|c|c|c|c|c|}
\hline Vuodet, Years & 1963 & 1964 & 1965 & 1966 & 1967 \\
\hline Keritty uuhia & 19 & 31 & 43 & 47 & 51 \\
\hline \multicolumn{6}{|l|}{ Sheared ewes } \\
\hline karitsoita & 15 & 15 & 16 & 22 & 54 \\
\hline lambs & & & & & \\
\hline pässejä & 1 & 1 & 1 & - & 1 \\
\hline rams & & & & & \\
\hline Villatuotos yht. kg & 82 & 94 & 127 & 114 & 186 \\
\hline \multicolumn{6}{|l|}{ Wool output, total, $\mathrm{kg}$} \\
\hline \multirow{2}{*}{$\begin{array}{l}\text { Karitsain ja pässin villatuotos } \mathrm{kg} \\
\text { Wool output of lambs and ram, } \mathrm{kg}\end{array}$} & 18 & 18 & 20 & 22 & 57 \\
\hline & & & & & \\
\hline Uuhien villatuotos $\mathrm{kg} / \mathrm{uuhi}$ & 3.4 & 2.5 & 2.5 & 2.0 & 2.5 \\
\hline
\end{tabular}

Villaa on saatu vuosina 1963-67 keskimäärin 2.5 kg uuhta kohti. Syksyllä kerittyjen karitsain villatuotokseksi on saatu keskimäärin $1.0 \mathrm{~kg}$ karitsaa kohti. Kokonaisvillatuotos on laskettu kauppaliikkeiden tilitysten mukaan. Villasta on kuulunut II luokkaan $69.8 \%$, III luokkaan $29.9 \%$ ja IV luokkaan $0.3 \%$. Villatuotos on ollut vähän suurempi kuin tarkkailukatraiden keskituotos ja laatu on ollut selvästi parempi kuin keskimäärin kauppaliikkeisiin tulleen villan laatu (Lammastoimikunnan mietintö II 1965).

\section{Tuotto}

Taulukkoon 6 on laskettu lammastalouden kokonaistuotto vuosilta 1965-1967. Kunkin vuoden kokonaistuotto on laskettu vuoden 1967 hintojen mukaan. Lampaanlihan hin-

Taulukko 6. Lammastalouden kokonaistuotto vuosina 1965-1967.

Table 6. Gross return from sheep husbandry in 1965-1967.

\begin{tabular}{|c|c|c|c|c|c|c|c|}
\hline & \multicolumn{3}{|c|}{1965} & \multicolumn{2}{|c|}{1966} & \multicolumn{2}{|c|}{1967} \\
\hline Lihaa & $546 \mathrm{~kg}$ & $3003 \mathrm{~m}$ & $\mathrm{mk}$ & $622 \mathrm{~kg}$ & $3405 \mathrm{mk}$ & $334 \mathrm{~kg}$ & $1818 \mathrm{mk}$ \\
\hline \multicolumn{8}{|l|}{ Meat } \\
\hline Villaa II & $98 »$ & $1076 m$ & $"$ & $87 »$ & $960 "$ & $113 "$ & $1240 "$ \\
\hline \multicolumn{8}{|l|}{ Wool } \\
\hline$" \quad$ III & $29 "$ & $201 n$ & $m$ & $27 m$ & $190 "$ & $73 n$ & $513 \#$ \\
\hline Elävänä myydyt & $9 \mathrm{kpl}$ & $670 m$ & $"$ & $10 \mathrm{kpl}$ & $656 »$ & $17 \mathrm{kpl}$ & $2610 "$ \\
\hline \multicolumn{8}{|l|}{ Sold alive } \\
\hline Katraan lisäykseen & $8 "$ & $800 »$ & $n$ & $9 "$ & $900 "$ & $40 "$ & $4000 "$ \\
\hline \multicolumn{8}{|l|}{ For breeding } \\
\hline Lanta & & $84 »$ & $n$ & & $102 "$ & & $120 "$ \\
\hline \multicolumn{8}{|l|}{ Manure } \\
\hline Tuotto yhteensä & \multicolumn{3}{|c|}{$5834 \mathrm{mk}$} & \multirow{2}{*}{\multicolumn{2}{|c|}{$6213 \mathrm{mk}$}} & \multicolumn{2}{|r|}{$10301 \mathrm{mk}$} \\
\hline \multicolumn{6}{|l|}{ Return, total } & & \\
\hline Tuotto mk/uuhi & \multirow{2}{*}{\multicolumn{3}{|c|}{139}} & \multirow{2}{*}{\multicolumn{2}{|c|}{132}} & \multirow{2}{*}{\multicolumn{2}{|c|}{215}} \\
\hline Return mk/ewe & & & & & & & \\
\hline
\end{tabular}


tavaihtelut ovat olleet myyntiajankohdasta riippuen huomattavat (Tuottajahintatilastoa 1965-67). Lihan hinta on ollut seuraavaa:

$\begin{array}{lllll} & & 1965 & 1966 & 1967 \\ \text { Lihan hinta Honkasuon tilalla mk } & 4.60 & 5.03 & 5.50 \\ \text { Elokuun keskihinta koko maassa " } & 3.99 & 4.69 & 5.13 \\ \text { Vuoden keskihinta " " } " 3.70 & 4.25 & 4.59\end{array}$

Vuosina 1965 ja 1966 elävänä myydyt karitsat olivat 2-4 kuukauden ikäisiä mutta vuosina 1967 myydyistä 14 oli yli 6 kuukauden ikäistä. Elävänä myytyjen hinnan vuosivaihtelut aiheutuvat lähinnä tästä seikasta. Katraan lisäykseen käytettyjen karitsain arvo on arvioitu todennäköisen lihatuotoksen ja lihan korkeimman kausihinnan mukaan.

Villan hintana on pidetty vuoden 1967 keskimääräistä tilityshintaa, joka oli II:n luokan villalla $11 \mathrm{mk}$ ja III luokan villalla $7 \mathrm{mk}$ kilolta.

\section{Kustannukset}

Rehukustannus muodostaa lammastalouden suurimman kustannuksen. Rehuista on ollut karkeata rehua (kuivaa heinää, tuorerehua, laidunta, vihantarehua) keskimäärin $87 \%$. Kun markkinoilla oleva karkea rehu (heinä) muodostaa häviävän pienen osan kaikesta käytetystä karkeasta rehusta, muodostuu karkean rehun hinta epämääräiseksi ja yleensä niin korkeaksi, ettei ostetun karkean rehun varaan ole perustettu kotieläintaloutta. Karkean rehun keskimääräinen markkinahinta ei ilmaise näille rehuille kotieläintaloudessa saatavaa korvausta. Karkean rehun arvo on määritettävissä lähinnä kotieläintaloudesta saadun taloudellisen tuloksen avulla. Maatalouden kannattavuustutkimuksen yhteydessä on aiemmin laskettu noin sadalta tilalta karkean rehun korvaushinta. Se on muodostunut vuosien 1960 - 63 keskiarvona $0.20 \mathrm{mk} / \mathrm{ry}$. Vuoden 1963 jälkeen karkean rehun jalostusarvolaskelmaa ei ole tehty. Tiloilla, joilta karkean rehun jalostusarvo on laskettu on karjan keskituos ollut $21.6 \%$ korkeampi kuin karjan keskituotos maan kaikilla tiloilla. Kun myöhemmin esitettävissä laskelmissa selvitellään lammastalouden suhteellista kannattavuutta, on karkeiden rehujen arvoksi laskettu noin $0.20 \mathrm{mk} / \mathrm{ry}$. Tämä lienee lähellä karkean rehun keskimääräistä jalostusarvoa myös lypsykarjataloudessa.

T y ö k u s t a n n u s t e n laskeminen on näin pienessä katraassa (50 uuhta) epätarkkaa. Kesän aikana tarvitaan ihmistyötä lähinnä laidunten ja aitojen hoitoon ja kunnossapitoon sekä valvomiseen, että lampailla on ruokaa ja juomaa ja että sairaille lampaille järjestetään hoitoa. Viidenkymmenen lampaan katraassa, jos laitumet ovat lähellä talouskeskusta, tällaiseen työhön käytettyä aikaa on lähes mahdotonta tarkkailla. Työnmenekki lienee $0.5-1.0$ tuntia päivässä. Jos katraan koko olisi huomattavasti suurempi, työnmenekin laskeminen kesäaikana alkaisi muodostua mielekkääksi. Sisäruokintakauden aikana aina karitsoimiseen saakka työnmenekki lienee 1.0-1.5 tuntia päivässä. Karitsoimisaika on lammastalouden työhuipun aikaa. Jo 50 uuhen katraassa työnmenekki nousee 2-4 tuntia päivässä. Tämä kausi kestää karitsoimisen yhtäaikaisuudesta riippuen $2-4$ viikkoa. Vuotuinen työnmenekki 50 uuhen katraassa lienee 400-500 tuntia. Yhtä uuhta kohti olisi työnmenekki 8-10 tuntia. Pieniä katraita hoidettaessa työnmenekki näyttää muodostuvan huomattavan suureksi. Tämän tutkimuksen kannattavuuslaskelmat on tehty edellyttäen, että työnmenekki uuhta kohti olisi 8 tuntia. Työtunnin hintana on käytetty $2.50 \mathrm{mk}$. 
R a k e n n u k us t a n n u k et. Pääoman korko on laskettu $5 \%$ :n mukaan puolelle pääomaa. Poisto on laskettu $5 \%$ :ksi rakennusten nykyarvosta, joka oli $8500 \mathrm{mk}$. Kunnossapitokustannus on laskettu todellisten kustannusten mukaan.

A i t a k u s tann s on laskettu edellyttäen, että aitaverkko kestäisi 20 vuotta ja aitapylväät 10 vuotta. Aitojen perustamiskustannus on muodostunut Honkasuolla seuraavaksi:

\begin{tabular}{|c|c|c|c|c|}
\hline Aitaverkkoa & $2200 \mathrm{~m}$ & à $0.82 \mathrm{mk}$ & $1804 \mathrm{~m}$ & $\mathrm{mk}$ \\
\hline Aitapylväitä & $750 \mathrm{kpl}$ & $0.60 "$ & $450 m$ & $"$ \\
\hline Pintalautaa & $2200 \mathrm{~m}$ & à 0.05 " & $110 m$ & $"$ \\
\hline Naulat ja määrlyt & & & $30 "$ & $"$ \\
\hline Perustamistyötä & $160 \mathrm{t}$ & à $2.50 "$ & $400 m$ & $"$ \\
\hline
\end{tabular}

Perustamiskustannus on $1.27 \mathrm{mk} / \mathrm{m}, 400 \mathrm{mk} / \mathrm{ha}$ ja $56 \mathrm{mk} / \mathrm{uuhi}$. Vuotuisen kunnossapidon on arvioitu vaativan yhden työtunnin 100 aitametriä kohti. Kymmenen vuoden kuluttua painekyllästämättömät aitapylväät joudutaan uusimaan, jolloin tarvitaan perustamistyötä sama määrä kuin aitoja ensi kertaa rakennettaessa. Vuotuiseksi kustannukseksi tulee $16 \mathrm{mk} / 100$ aitametriä ja n. $6 \mathrm{mk} /$ uuhi.

Te rveyde n h o t o k u s t a n u s on vaihdellut nollasta 4.30 markkaan karitsoinutta uuhta kohti vuodessa. Keskimääräinen kustannus uuhta kohti on ollut $3.20 \mathrm{mk}$. Tämä kustannus on ylittänyt noin markalla ne ohjeluvut, joita on esitetty esim. ruotsalaisessa alan kirjallisuudessa (Gustafsson ja SjöBerg 1966).

P ä s s i on hankittu tilalle ostamalla. Pässin hinta on ollut vuosina 1965-67 keskimäärin 200 mk. Kun pässeistä on saatu teuraina keskimäärin 135 mk, ovat pässistä aiheutuneet rahamenot olleet $65 \mathrm{mk}$ vuotta kohti. Tämän lisäksi pässistä aiheutuneita kustannuksia ovat olleet elatusrehu- ja lääkintäkustannus. Pässikustannuksiin kuuluu myös osuus rakennus-, työ-, valaistus- ja aitauskustannuksista. Näitä ei ole eritelty, vaan ne muodostavat osan lammastalouden kustannuksista.

E 1 ä in t e n u u s in t a tapahtuu jatkuvassa lammastaloudessa siten, että osa uuhista teurastetaan ja karitsoista kasvatetaan uusia emiä. Kannattavuuslaskelmissa voidaan jättää pois uusimiseen tarvittavien uuhien kasvatuskustannus. Kasvava uuhi rasittaa lammastaloutta kuluttamillaan rehuilla, lisätyllä rakennus-, työ-, lääkintä- yms. kustannuksilla, jotka voidaan katsoa kuuluvan välttämättömänä osana uuhien ylläpidosta aiheutuviin kustannuksiin. Kun aiemmin tässä tutkimuksessa on esitetty uuhien rehun käyttö, on myös uusimiseen ja pässin elatukseen tarvittu rehu laskettu mukaan esitettyihin rehun kulutusta osoittaviin lukuihin. Vuotuinen uusimistarve on arvioitu $20 \%$ :ksi katraan uuhien määrästä.

$\mathrm{S}$ ä h k ök u s t a n n s perus- ja vuotuismaksuineen on ollut $1.33 \mathrm{mk}$ uhta kohti. Sähkövirtaa on käytetty lähinnä valaistukseen lampolassa, eteisessä, varastoissa ja pihalla sekä keritsemisessä. Vuotuiskulutus 50 uuhen katraassa on ollut n. 350 kwt.

Se ka la isiin kustannuksi in on luettu kantakirjaamisesta, kirjanpidosta, ammattijulkaisuista, näyttelyistä ja muista em. kaltaisista hankinnoista ja toimenpiteistä aiheutuneet menot. Nämä kustannukset ovat olleet noin $1.00 \mathrm{mk} / \mathrm{uuhi}$.

Eläimiin joudutaan sitomaan pääomaa. Tälle pääomalle on laskettu $6 \%$ :n korko. Yhtä aikuista uuhta kohti on arvioitu sijoitetun pääomaa 100 markkaa.

Taulukkoihin 7-10 on laskettu lammastalouden antama kokonaistuotto, liikekustan- 
nus, puhdas tuotto, katetuotto ja karkeiden rehujen jalostusarvo, jota voidaan pitää eräänä katetuottolaskelman haarana.

Honkasuon tilan lampaiden tuotokset vastaavat suunnilleen tuotannontarkkailusta saatuja keskimääräisiä tuloksia. Kun teoreettisesti joka toisessa tapauksessa saadaan keskiarvoa parempi tulos, on taulukkoihin laskettu myös lammastalouden antama taloudellinen tulos keskiarvoa paremmissa tapauksissa. Näiden laskelmien tiedot (rehunkulutuksen, työnmenekin, riskinvaaran, terveydenhoitomenojen ym. lisääntyminen) ovat lähinnä järjestetyistä kokeista saatuja.

Karitsatuotos lisääntyy karitsoiden nopeamman kasvukyvyn, karitsoiden teurasiän lisääntymisen ja suuremman karitsaluvun ansiosta. Ilmeisesti rehunkulutuksen lisäys ei ole kaikissa mainituissa tapauksissa lisäkasvukiloa kohti täysin sama. NIELSEN (1960) laskee rehunkulutuksen yhtä lisäkasvukiloa kohti viideksi rehuyksiköksi. JoHnsson et al. (1960) laskee 11 ry lisää rehua uuhta kohti, jos karitsaluku kasvaa 0.1:1lä yksiköllä emää kohti ja karitsain teuraspaino on $12.5 \mathrm{~kg}$. JoHnsson laskee rehunkulutukseksi mukaan luettuna myös elatusrehu 28-37 kilon painoisille karitsoille 9-14 ry teuraspainokiloa kohti. Vaihtelu aiheutuu karitsain iästä ja kasvunopeudesta. Kun taulukkoihin 9-10 on laskettu karitsatuotoksen lisäyksen aiheuttama rehukustannus, on jokaista emän tuottamaa lisäkaritsaa kohti laskettu tarvittavan rehua 110 rehuyksikköä edellyttäen, että karitsain teuraspaino on $\mathrm{n} .12 \mathrm{~kg}$.

Kun rehunkulutuksen arvioiminen on epävarmaa ja rehukustannus muodostaa suuren osan liikekustannuksesta, muodostuu esim. lammastalouden puhtaan tuoton laskeminen tästäkin syystä hyvin epävarmaksi. Jos sen sijaan lampaanhoidon taloudellisuutta arvostelemme lampaiden käyttämille rehuille saadun jalostusarvon mukaan, väärin arvioitu rehunkulutus aiheuttaa ry:n jalostusarvoon suhteellisesti pienemmän virheen kuin rehunkulutus on väärin arvioitu. Rehunkulutuksen virhearviointi lienee korkeintaan $\pm 10 \%$, joten ry:n jalostusarvon virherajat jäävät lähelle näitä rajoja edellyttäen, että muut kustannukset on arvioitu oikein. Kun muitten kuin rehukustannusten osuus liikekustannuksesta on vajaa kolmannes, muitten kustannusten arvioimisvirhe ei voi vaikuttaa huomattavasti ry:n jalostusarvoon.

\section{Kannattavuus}

Lammastalouden puhdas tuotto muodostui negatiiviseksi $12 \mathrm{mk}$ uuhta kohti (taulukko 7). Kun kaikki rehut ja työ hinnoitetaan markkinahinnan mukaan, on sangen tavallista, että puhdasta tuottoa ei muodostu enempää lammas- kuin nautakarjataloudessakaan. Puhdastuottolaskelmien sijasta yleisempiä nautakarjataloudesta tehtyjä laskelmia ovat olleet jalostusarvolaskelmat ja aivan viime vuosina katetuottolaskelmat.

Karkeiden rehujen jalostusarvoksi jäi Honkasuon tilalla 16 penniä rehuyksikköä kohti (taulukko 8 ja kuvio 2). Kun otetaan huomioon kaikki kotoiset rehut, oli jalostusarvo 19 penniä rehuyksikköä kohti. Kun hehtaarilta saatiin noin 2500 ry:ä laidunrehua, tuorerehua, heinää ja kauraa, maksoi lammastalous näistä rehuista $475 \mathrm{mk}$ rehualan hehtaaria kohti.

Taulukkoon 9 on laskettu karkeiden rehujen jalostusarvo tuotostason muuttuessa. Taulukko antaa havainnollisen kuvan siitä, minkä verran karitsatuotoksen lisäys vaikuttaa rehujen jalostusarvoon. Karitsaluvun muuttuessa 0.1:1lä muuttuu ry:n jalostusarvo noin 


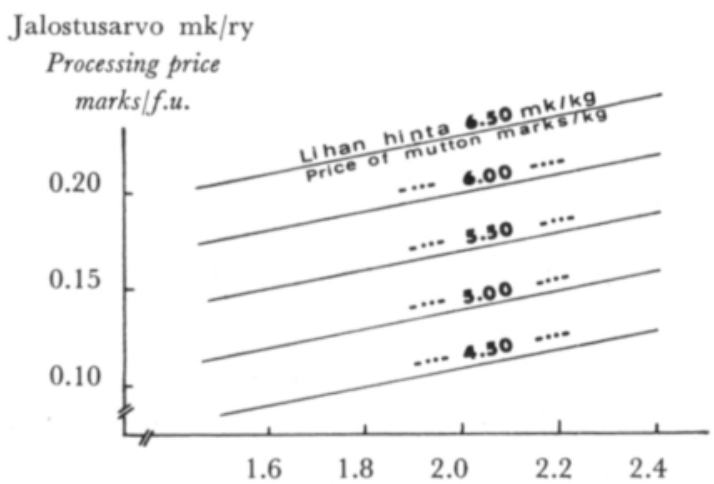

Karitsaluku unta kohti Number of lambs per ewe

Kuvio 2. Karkean rehun jalostusarvon riippuvuus karitsaluvusta ja lihan hinnasta.

Fig. 2. The processing price of roughage as a function of the number of lambs per ewe and the price of mutton.

Taulukko 7. Lammastalouden keskimääräinen kokonaistuotto, liikekustannus ja puhdas tuotto Malminkartanon tilalla vuosina $1965-67$.

Table 7. Gross return, production costs and net return of sheep husbandry at Malminkartano Farm, average 1965-1967.

Kokonaistuot to Cross return (Table 6)

$\mathrm{Mk} / \mathrm{katras}$ marks/flock 7449

Liikekustannus: Production costs:

Tuku Concentrate

Kaurajauhot

Oatmeal

Mineral supplem.

Kuiva heină

Hay

Säilörehu

Oljet

Silage

Straw

Pasture

Laidun

Total

Rakennuskustannus Building

Kalusto

Ihmistyö

Aitaus

Sähkö

Kuivikkeet

Terveyden hoito

Eläinten ostot

\section{Equipment}

Labour

Fencing

Electricity

Litters

Veterinary

Sekalaiset menot

Purchase of animals

$310 \mathrm{~kg}$ à 0,63

3412 ” 0,35

$19240 》 0,10$

2681 ry 0,20

$1930 \mathrm{~kg} \quad 0,03$

9733 ry 0,18

Miscellaneous

Yhteensä

Total

Lammastalouden puhdas tuotto

Net return of sheep husbandry

$\begin{array}{lll}195 & 4,33 & 2.4\end{array}$

$1194 \quad 26,54 \quad 15.0$

$\begin{array}{lll}73 & 1,62 & 0.9\end{array}$

$1924 \quad 42,76 \quad 24.1$

$\begin{array}{lll}536 & 11,91 & 6.7\end{array}$

$\begin{array}{lll}58 & 1,29 & 0.7\end{array}$

$1752 \quad 38,93 \quad 21.9$

$\begin{array}{lll}5732 & 127,38 & 71.7\end{array}$

$\begin{array}{lll}595 & 13,22 & 7.5\end{array}$

$\begin{array}{lll}30 & 0,67 & 0.4\end{array}$

$913 \quad 20,29 \quad 11.4$

$\begin{array}{lll}275 & 6,11 & 3.4\end{array}$

$\begin{array}{lll}60 & 1,33 & 0.8\end{array}$

$43 \quad 0,96 \quad 0.5$

$\begin{array}{lll}159 & 3,53 & 2.0\end{array}$

$\begin{array}{lll}133 & 2,95 & 1.7\end{array}$

\begin{tabular}{lll}
44 & 0,98 & 0.6 \\
\hline
\end{tabular}

$\begin{array}{lll}7984 & 177,42 & 100.0\end{array}$

$-535 \quad-11,89$

$3 \%$. Sen sijaan viiden prosentin muutos lihan hinnassa saa aikaan n. $10 \%$ :n muutoksen karkeiden rehujen jalostusarvoon (kuvio 2).

Ihmistyö- ja rakennuskustannuksen laskeminen saattaa olla eräissä tapauksissa vaikeaa ja tuotantosuuntaa valitessa tarpeetonta. Taulukkoon 10 on laskettu ihmistyölle, rakennuk- 
Taulukko 8. Karkean rehun jalostusarvolaskelma lammastalouden keskimääräisten tulosten mukaan vuosina $1965-67$.

Table 8. Processing price for roughage at Malminkartano Farm, average 1965-1967.

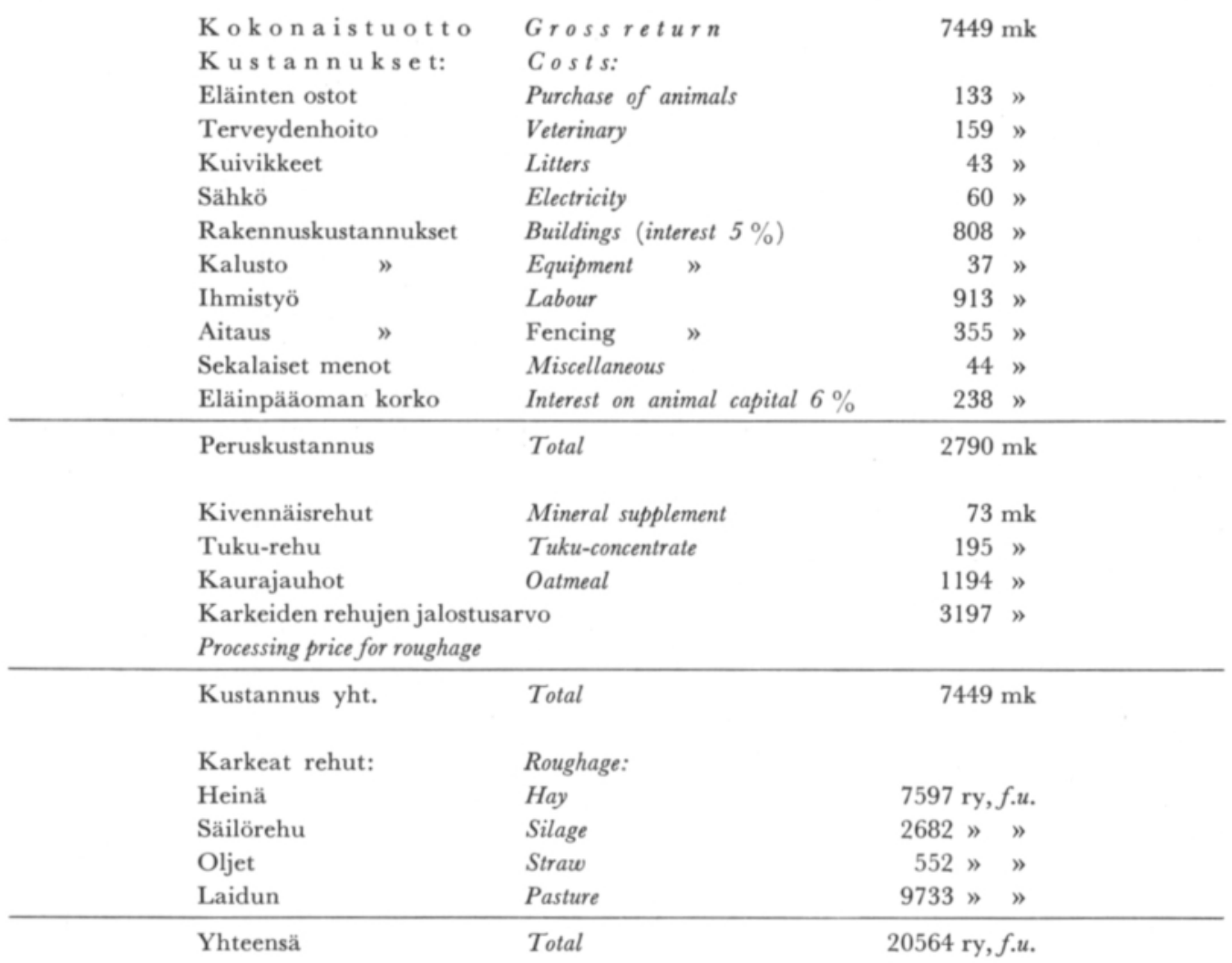

Karkean rehun jalostusarvo $0.16 \mathrm{mk} / \mathrm{ry}$

Processing price for roughage 0.16 marks/fodder unit

sille ja pääoman koroksi jäävä katetuotto tuotostason muuttuessa. Rehut on hinnoitettu markkinahinnan mukaan. Karitsatuotoksen kasvaessa 1.8:sta 2.2:een uuhta kohti lisääntyy katetuotto taulukossa 10 esitetyin perustein lähes kaksinkertaiseksi. Kun ihmistyö, rakennusja korkokustannus muodostavat vain vajaa neljäsosan tuotantokustannuksesta, vaikuttaa pienikin tuoton muutos suhteellisesti suuren muutoksen katetuottoon.

\section{Lammas- ja nautakarjatalouden vertailu}

Lammas käyttää suuressa määrin samoja rehuja kuin lihaksi kasvatettava nauta ja lypsylehmä. Sekä lampaan- että naudanlihan tuotantokustannuksista rehukustannus muodostaa ylivoimaisesti suurimman kustannuksen. Maidon tuotantokustannuksista myös ihmistyö sekä rakennus- ja kalustokustannus näyttelevät merkittävää osaa. Tuotantoaan suunnitteleva viljelijä 'outuu vertaamaan keskenään eri tuotantomuotojen ja tuotannonhaarojen suhteellista kannattavuutta. Seuraavassa on suoritettu kaavamainen vertailu lihan tuotan- 
Taulukko 9. Karkean rehun jalostusarvolaskelma. Esimerkkejä tuotostason muuttuessa; vuoden 1967 hintatason mukaan; $50-60$ uuhen katras.

Table 9. Processing price calculation for roughage. Examples when the number of lambs/ewe changes; price level for 1967; a flock of about 50-60 ewes.

\begin{tabular}{|c|c|c|c|c|c|c|c|c|}
\hline \multirow[b]{2}{*}{ Tuot to: } & \multirow[b]{2}{*}{ Return: } & \multicolumn{3}{|c|}{$\left.\mathrm{I}^{\mathbf{1}}\right)$} & \multicolumn{2}{|c|}{ II } & \multicolumn{2}{|c|}{ III } \\
\hline & & $\begin{array}{l}\text { Määrä } \\
\text { Quantity }\end{array}$ & $\begin{array}{c}\text { Hinta } \\
\text { Price }\end{array}$ & $\begin{array}{c}\mathrm{mk} \\
\text { Marks }\end{array}$ & $\begin{array}{l}\text { Määrä } \\
\text { Quantity }\end{array}$ & $\begin{array}{c}\mathrm{mk} \\
\text { Marks }\end{array}$ & $\begin{array}{l}\text { Määrä } \\
\text { Quantity }\end{array}$ & $\begin{array}{c}\mathrm{mk} \\
\text { Marks }\end{array}$ \\
\hline Lihaa, karitsat & Meat, lambs & 19.0 & 5,50 & 104,50 & 21.5 & 118,25 & 24.0 & 132,00 \\
\hline " uuhi & $"$ ewe & 4.5 & 4,00 & 18,00 & 4.5 & 18,00 & 4.5 & 18,00 \\
\hline Villaa II & Wool I & 1.7 & 9,00 & 15,30 & & 15,30 & & 15,30 \\
\hline$"$ III & Wool III & 0.8 & 5,00 & 4,00 & & 4,00 & & 4,00 \\
\hline Lanta & Manure & & & 2,50 & & 2,50 & & 2,50 \\
\hline Yhteensä & Total & & & 144,30 & & 158,05 & & 171,80 \\
\hline Kustannukset: & Costs: & & & & & & & \\
\hline Pässikustannus & Ram & & & 2,00 & & 2,00 & & 2,00 \\
\hline Terveyden hoito & Veterinary & & & 1,50 & & 1,75 & & 2,00 \\
\hline Kuivikkeet & Litters & 50 & 0,03 & 1,50 & & 1,50 & & 1,50 \\
\hline Sähkö & Electricity & 60 & 0,20 & 1,20 & & 1,20 & & 1,20 \\
\hline Rakennuskustannus & Building & & & 10,00 & & 10,00 & & 10,00 \\
\hline Kalusto " & Equipment & & & 1,00 & & 1,00 & & 1,00 \\
\hline Aitaus & Fencing & & & 6,50 & & 6,50 & & 6,50 \\
\hline Ihmistyö " " & Labor & 8 & 2,50 & 20,00 & & 22,50 & & 25,00 \\
\hline Sekalaiset menot & Miscellaneous & & & 1,50 & & 1,50 & & 1,50 \\
\hline Eläinpääoman korko & $\begin{array}{c}\text { Interest on animal } \\
\text { capital, } 6 \%\end{array}$ & & & 6,00 & & 6,50 & & 7,00 \\
\hline Yhteensä & Total & & & 51,20 & & 54,45 & & 57,70 \\
\hline Kivennäisrehut & Mineral supplements & & & 2,50 & & 2,75 & & 3,00 \\
\hline Tuku-rehu & Tuku-concentrate & 5 ry & & 5,20 & 6 ry & 6,25 & 7 ry & 7,30 \\
\hline Kaurajauhoja & Oatmeal & $50 "$ & & 21,00 & $55 "$ & 23,10 & $60 "$ & 25,20 \\
\hline $\begin{array}{l}\text { Karkeiden rehujen } \\
\text { jalostusarvo }\end{array}$ & $\begin{array}{l}\text { Processing price for } \\
\text { roughage }\end{array}$ & $405 n$ & & 64,40 & $420 "$ & 71,50 & $435 »$ & 78,60 \\
\hline Yhteensä & Total & & & 144,30 & & 158,05 & & 171,80 \\
\hline $\begin{array}{l}\text { Karkeiden rehujen } \\
\text { jalostusarvo mk/ry }\end{array}$ & $\begin{array}{l}\text { Processing price for } \\
\quad \text { roughage marks } \mid f . u\end{array}$ & & & 0,16 & & 0,17 & & 0,18 \\
\hline
\end{tabular}

1) Karitsoita/uuhi laskelma I:n mukaan 1.8, II:n mukaan 2.0 ja III:n mukaan 2.2, joiden teuraspaino on $12 \mathrm{~kg}$.

Lambs/ewe: 1.8 according to calculation I, 2.0 according to II and 2.2 according to III; carcass weight $12 \mathrm{~kg}$.

non edullisuudesta. Vertailu on suoritettu laskemalla eri tapauksissa saatava karkean rehun jalostusarvo (taulukot 10-11).

Naudanlihan jalostusarvoa koskevat laskelmat on tehty edellyttäen, että lihan tuottaminen tapahtuisi Honkasuon tilalla, jolta tämän tutkimuksen aineisto on saatu. Lihakarjaa on arvioitu pidettävän se määrä, joka voitaisiin kasvattaa lampaiden käyttämällä rehumäärällä (24000 ry). Kaikki kiinteät kustannukset (työ-, rakennus-, kalusto-, aitauskustan- 
Taulukko 10. Lammastalouden katetuottolaskelma. Esimerkkejä tuotostason muuttuessa; vuoden 1967 hintatason mukaan; $50-60$ uuhen katras.

Table 10. Gross margin calculation for sheep husbandry. Examples when the number of lambs/ewe changes; price level for 1967; a flock of about 50-60 ewes.

\begin{tabular}{|c|c|c|c|c|c|c|c|c|}
\hline \multirow[b]{2}{*}{ Tuot to: } & \multirow[b]{2}{*}{ Return: } & \multicolumn{3}{|c|}{ I } & \multicolumn{2}{|c|}{ II } & \multicolumn{2}{|c|}{ III } \\
\hline & & Määrä & $\begin{array}{c}\text { Hinta } \\
\text { Price }\end{array}$ & $\begin{array}{c}\text { mk } \\
\text { Marks } \\
144,30\end{array}$ & $\begin{array}{l}\text { Määrä } \\
\text { Quantity }\end{array}$ & $\begin{array}{c}\text { mk } \\
\text { Marks } \\
158,05\end{array}$ & $\begin{array}{l}\text { Määrä } \\
\text { Quantity }\end{array}$ & $\begin{array}{c}\mathrm{mk} \\
\text { Marks } \\
171,80\end{array}$ \\
\hline \multicolumn{9}{|c|}{$\begin{array}{l}\text { M u t t u vat kustannuset: } \\
\text { Variablecosts: }\end{array}$} \\
\hline Tuku-rehu & Tuku-concentrate & 5 ry & 1,04 & 5,20 & 6 & 6,24 & 7 & 7,28 \\
\hline Kaurajauhot & Oatmeal & $50 m$ & 0,42 & 21,00 & 55 & 23,10 & 60 & 25,20 \\
\hline Heinä & Hay & $120 "$ & 0,25 & 30,00 & 120 & 30,00 & 120 & 30,00 \\
\hline Säilörehu & Silage & $40 "$ & 0,20 & 8,00 & 40 & 8,00 & 40 & 8,00 \\
\hline Laidun & Pasture & $245 »$ & 0,18 & 44,10 & 260 & 46,80 & 275 & 49,50 \\
\hline Kivennäisr. & Mineral suppl. & & & 2,50 & & 2,75 & & 3,00 \\
\hline Pässikustannus & Rams & & & 2,00 & & 2,00 & & 2,00 \\
\hline Terveydenhoito & Veterinary & & & 1,50 & & 1,75 & & 2,00 \\
\hline Sähkö & Electricity & & & 1,20 & & 1,20 & & 1,20 \\
\hline Rak. kunnossapito & Maintenance of but & & & 1,20 & & 1,20 & & 1,20 \\
\hline Kalustokustannus & Equipment & & & 1,00 & & 1,00 & & 1,00 \\
\hline Aitaus & Fencing & & & 4,00 & & 4,00 & & 4,00 \\
\hline Sekalaiset menot & Miscellaneous & & & 1,50 & & 1,50 & & 1,50 \\
\hline \multicolumn{8}{|c|}{ Eläinpääoman korko Interest on animal } & 7,00 \\
\hline Yhteensä & Total & & & 129,20 & & 136,04 & & 142,88 \\
\hline Katetuotto & Gross margin & & & 15,10 & & 22,01 & & 28,92 \\
\hline
\end{tabular}

nus) on jaettu tilalla pidettävän enimmäiseläinmäärän kesken. Kiinteät kustannukset rasittavat näin saman suuruisina eri tuotannonhaaroja.

Rehunkulutus on ollut Kotieläinhoidon tutkimuslaitoksen toimesta järjestetyissä nautaeläinten kasvatuskokeissa lihakiloa kohti eri kokeissa seuraava:

\begin{tabular}{|c|c|c|c|c|c|c|}
\hline Lihovasikka & & $7 \mathrm{kk}$ & $6.6-7.7$ & ry/lihakilo & (LARPES & 1968) \\
\hline Ruohovasikka & & $7 \mathrm{kk}$ & $6.5-6.8$ & $"$ & $"$ & 1965 \\
\hline Hieho & & $9 \mathrm{kk}$ & 8.2 & $"$ & $"$ & 1968 \\
\hline Sonni & & $11 \mathrm{kk}$ & 7.0 & $"$ & $"$ & 1968 \\
\hline Härkä & sk 17 ja & $24 \mathrm{kk}$ & 11.9 ja 12.9 & $"$ & $"$ & 1963 ja 1966 \\
\hline$"$ & ay & & 12.1 ja 12.3 & $"$ & $"$ & 1963 ja 1966 \\
\hline risteytys & & & $11.1-11.3$ & $"$ & $"$ & 1966 \\
\hline
\end{tabular}

Naudanlihan tuotantoon käytetään sekä sonni- että lehmävasikoita. Lehmävasikat näyttävät kokeiden mukaan käyttävän enemmän rehua lihakilon tuottamiseen kuin sonnit. On ilmeistä, että käytännön kotieläintaloudessa rehujen laatu, rehujen vitamiinien ja kivennäisaineiden suhteet sekä eläinten hoito ovat keskimäärin huonompia kuin alan asiantuntijain järjestämissä kokeissa. Rehun kulutus lihakiloa kohti lienee käytännön taloudessa 
Taulukko 11. Karkeiden rehujen jalostusarvo naudanlihan ja maidon tuotannossa.

Table 11. Processing price for roughage in the production of beef and milk.

\begin{tabular}{|c|c|c|c|c|c|c|c|c|c|c|}
\hline \multirow[b]{2}{*}{ Tuot o: } & \multirow[b]{2}{*}{ Return: } & \multicolumn{3}{|c|}{$\begin{array}{l}\text { Ruohovasikka } \\
\text { Calf, } 6-8 \text { months }\end{array}$} & \multicolumn{3}{|c|}{$\begin{array}{l}\text { Hieho, mulli } \\
\text { Heifer, yearling }\end{array}$} & \multicolumn{3}{|c|}{$\begin{array}{l}\text { Lypsylehmä, } \\
\text { Dairy cow }\end{array}$} \\
\hline & & $\begin{array}{l}\text { Määrä } \\
\text { Quantity }\end{array}$ & $\begin{array}{c}\text { Hinta } \\
\text { Price }\end{array}$ & $\begin{array}{c}\mathrm{mk} \\
\text { Marks }\end{array}$ & $\begin{array}{r}\text { Määrä } \\
\text { Quantity }\end{array}$ & $\begin{array}{c}\text { Hinta } \\
\text { Price }\end{array}$ & $\begin{array}{c}\mathrm{mk} \\
\text { Marks }\end{array}$ & $\begin{array}{r}\text { Määrä } \\
\text { Quantity }\end{array}$ & $\begin{array}{l}\text { Hinta } \\
\text { Price }\end{array}$ & $\begin{array}{c}\mathrm{mk} \\
\text { Marks }\end{array}$ \\
\hline Lihaa & Meat & 110 & 4.50 & 495 & 230 & 4,70 & 1081 & 36 & 4,00 & 44 \\
\hline Maitoa & Milk & - & & - & - & & - & 4000 & 0,46 & 1840 \\
\hline Vasikka & Calf & - & & - & - & & - & 1 & & 74 \\
\hline Lantaa & Manure & & & 10 & & & 40 & & & 40 \\
\hline Yhteensä & Total & & & 503 & & & 1121 & & & 2098 \\
\hline Kustannus: & Costs: & & & & & & & & & \\
\hline Vasikka, hieho & Calf, heifer & 1 & & 80 & 1 & & 80 & 1 & & 200 \\
\hline Astutus & Insemination & & & - & & & - & & & 30 \\
\hline Terveyden hoito & Veterinary & & & 5 & & & 15 & & & 35 \\
\hline Kuivikkeet & Litters & 150 & 0,03 & 5 & 800 & 0,03 & 24 & 800 & 0,03 & 24 \\
\hline Sähkö & Electricity & & & 2 & & & 10 & & & 25 \\
\hline Tarkkailu ym. & Testing, etc. & & & - & & & - & & & 15 \\
\hline Riski & Risk & & & 5 & & & 11 & & & 17 \\
\hline Rakennuskustannus & Building & & & 26 & & & 96 & & & 210 \\
\hline Kalusto $\quad "$ & Equipment & & & - & & & - & & & 70 \\
\hline Aitaus " & Fencing & & & 6 & & & 16 & & & 16 \\
\hline Ihmistyö " & Labor & & & 37 & & & 125 & & & 500 \\
\hline Eläinpääoman korko & $\begin{array}{c}\text { Interest on animal } \\
\text { capital, } 6 \%\end{array}$ & & & 11 & & & 58 & & & 48 \\
\hline Yhteensä & Total & & & 177 & & & 435 & & & 1190 \\
\hline Kivennäisr. vitam. & Minerals, vitamins & & & 5 & & & 15 & & & 30 \\
\hline Maito ja kurri & Milk, skim milk & 120 & 0,70 & 84 & 120 & 0,70 & 84 & & & - \\
\hline Kaura ja ohra & Oats and barley & 300 & 0,42 & 126 & 300 & 0,42 & 126 & 750 & 0,42 & 315 \\
\hline Valkuaisrehut & Protein fodder & - & & - & & & - & 150 & 0,65 & 98 \\
\hline Yhteensä & Total & & & 392 & & & 660 & & & 1633 \\
\hline $\begin{array}{l}\text { Karkean rehun jalos- } \\
\text { tusarvo }\end{array}$ & $\begin{array}{l}\text { Processing price for } \\
\text { roughage }\end{array}$ & & & 111 & & & 461 & & & 465 \\
\hline Karkeat rehut ry: & Roughage f.u.: & & & & & & & & & \\
\hline Kuiva heinä & Hay & 75 & & & 600 & & & 900 & & \\
\hline Säilörehu & Silage & & & & 850 & & & 350 & & \\
\hline Juurikasvit & Root crops & - & & & - & & & 100 & & \\
\hline Laidun & Pasture & 350 & & & 1100 & & & 800 & & \\
\hline Yhteensä & Total & 425 & & & 2550 & & & 2150 & & \\
\hline $\begin{array}{l}\text { Karkean rehun jalos- } \\
\text { tusarvo } \mathrm{mk} / \mathrm{ry}\end{array}$ & $\begin{array}{l}\text { Processing price } \\
\text { marks/f.u. }\end{array}$ & & & 0,26 & & & 0,18 & & & 0,22 \\
\hline
\end{tabular}


yllä esitetyistä syistä suurempi kuin kokeissa. Tässä suoritetuissa laskelmissa on ruohovasikan rehunkulutukseksi laskettu 7.7 ry ja 1.5 -2 vuotiaan hiehon ja sonnin tai härän rehunkulutukseksi 13 ry lihakiloa kohti.

Taulukkoon 11 on laskettu myös lypsykarjan karkean rehun jalostusarvo. Tämä laskelma perustuu kiinteitten kustannusten osalta arvioituihin kustannuksiin. Navetan ja tarpeellisten rehuvarastojen on arvioitu maksavan 9 lehmän karjassa $3000 \mathrm{mk}$ lehmää kohti. Vuotuiskustannukseksi on laskettu poistoa ja korkoa $6 \%$ (korko $5 \%$, kestoaika $40 \mathrm{v}$; ; annuiteetti on 5.83) ja kunnossapitoa $1 \%$ uudisarvosta. Kalustokustannus on arvioitu $20 \%$ :ksi kaluston (lypsykone, maidon jäähdyttäjä, astiat) uudisarvosta, joka on arvioitu 350 markaksi lehmää kohti. Työnmenekin on arvioitu olevan 5 työtuntia koko karjaa kohti päivässä ja 200 työtuntia lehmää kohti vuodessa. Lehmien tuotokseksi on oletettu $4000 \mathrm{~kg}$ maitoa vuodessa. Tuotos on 20 \% korkeampi kuin maan kaikkien karjojen keskituotos. On ilmeistä, että myös lihantuotantoa koskevat laskelmat ovat koko maan keskitasoa edullisempien edellytysten mukaan tehtyjä.

Rehunkäyttäjänä lammasta voidaan verrata lähinnä $1.5-2$ vuotiaaseen nautaan. Suoritetut laskelmat osoittavat, että lammas ja nuori nauta jalostavat suunnilleen yhtä taloudellisesti karkean rehun. Muista kuin rehuista aiheutuvien kustannusten väärin arvioimismahdollisuus on molemmissa tapauksissa yhtä suuri. Nämä kustannukset ovat samat lammastaloudessa ja naudan kasvattamisessa ja näiden osuus tuotantokustannuksesta on molemmissa tapauksissa lähes yhtä suuri.

Ruohovasikan kasvattaminen muodostuu intensiivisenä ja rationaalisena tuotantomuotona nykyisten lihan hintasuhteitten vallitessa edullisemmaksi kuin lammastalous. Karkean rehun jalostusarvo on ruohovasikan kasvattamisessa kuitenkin epävarmempi mitta kuin lammastaloudessa ja nuoren naudan kasvattamisessa, koska karkean rehun osuus ruohovasikan tuotantokustannuksesta on vain noin viidesosa. Ruohovasikan rehunkulutus voi olla edullisissa oloissa pienempi kuin taulukossa 11 on edellytetty, jolloin tämä tuotanto olisi vielä edullisempaa kuin tässä on esitetty. Toisaalta ruohovasikan tuottaminen käytännön kotieläintaloudessa on usein varsin ekstensiivistä vasikan kasvutaipumuksen hyväksikäyttöä. Tämä aiheuttanee suuremman rehunkulutuksen kuin kokeet osoittavat.

Taulukossa 11 esitetty lypsylehmän käyttämän karkean rehun jalostusarvo on 2 penniä ry:tä kohti korkeampi kuin maatalouden kannattavuustutkimuksessa vuosina 1960 -63 (sivu 111). Karkean rehun jalostusarvo on muodostunut lypsykarjataloudessa paremmaksi kuin lammastaloudessa. Edellytyksenä on keskitasoa korkeampi maitotuotos. Maitotuotoksen jäädessä keskimäärää pienemmäksi myös karkean rehun jalostusarvo pienenee. Maan keskitasoa huonommissa karjoissa karkean rehun jalostusarvo jäänee lähes samalla tasolle kuin lammastaloudessa.

\section{$P$ ä ätel miä}

Lampaan- ja naudanlihan sekä maidon tuottamiseen käytetään pääasiallisesti heinää, laidunta ja tuorerehua. Nämä kotieläintalouden tuotannonhaarat joutuvat kilpailemaan keskenään mainituista rehuista. Yrittäjä pyrkii valitsemaan sen tai ne tuotannonhaarat, jotka ovat hänen yksityistaloutensa kannalta edullisimpia ja toteuttamiskelpoisimpia.

Lammastalous on ekstensiivinen tuotannonhaara. Ennen kaikkea ihmistyövoiman tarve pinta-alayksikköä kohti on pieni. Kääntäen voidaan sanoa, että peltoalan tarve yhtä työn- 
tekijää kohti on lammastaloudessa olosuhteisiimme verrattuna hyvin suuri. Koska ihmistyövoimaa on ollut maatiloilla runsaasti peltoalaan verrattuna, työvoimaa intensiivisesti käyttävä tuotannonhaara on vahvistunut tai säilyttänyt asemansa. Lypsykarjatalous on ollut työvoimaa runsaasti käyttävänä tuotannonhaarana ylivoimainen lammastalouteen verrattuna. Lammastalouden supistumiseen on myötävaikuttanut lisäksi luonnonlaidunten käyttömahdollisuuden huomattava vaikeutuminen (Lammastoimikunnan mietintö).

Työvoiman siirtyminen pois maatiloilta ja työntekijäin vanheneminen vähentävät jatkuvasti maatalouden työvoimakapasiteettiä. Maatiloilla oleva työvoima hakee nyt ja tulevaisuudessa vielä enemmän tuotantomuotoja ja tuotannonhaaroja, jotka eivät sido työntekijää niin kiinteästi kuin lypsykarjatalous. Tällöin tulevat kysymykseen myös työtä ekstensiivisesti käyttävät tuotannonhaarat kuten lammastalous ja naudanlihan tuottaminen.

Lammastalouden edellytykset kilpailla maidon ja naudanlihan tuottamisen kanssa ovat parantuneet myös siksi, että lampaanlihan hinta on kohonnut nopeammin kuin maidon ja naudanlihan hinta. Vuonna 1952 sai tuottaja lampaanlihasta 8.6 kertaa korkeamman hinnan kuin $4 \%$ :sta maidosta. Vuonna 1967 oli hintojen suhde 10.3. Lampaanlihan tuottajahinta oli vuonna 1952 keskimäärin $13 \%$ korkeampi kuin naudanlihan. Vuonna 1967 ero oli $19 \%$ lampaanlihan hyväksi.

Lampaan ruokinnan ja hoidon tekniikkaa on kehitetty huomattavasti viime vuosina mm. Norjassa, Ruotsissa ja Suomessa. Huomiota on kiinnitetty erityisesti suurten katraitten laidun- ja sisäruokinnan järjestelyyn, hoitotyön rationalisointiin ja terveyden hoitoon. Suuret katraat ovat ilmeisesti entistä kilpailukykyisempiä. Tätä osoittaa mm. Ruotsin lammasluvun lisäys noin 2 kertaiseksi viimeisen 8 vuoden aikana. Lampaiden lisäys on tapahtunut lähinnä suurehkoja katraita lisäämällä.

Esitetyt karkean rehun jalostusarvolaskelmat osoittavat, että lammas maksaa nykyisten hintasuhteitten vallitessa keskimäärin alhaisemman korvaushinnan karkeista rehuista kuin keskitasoa oleva lypsylehmä tai teuraaksi kasvatettava nuori (alle 1-vuotias) nauta. Sen sijaan lammas näyttää pystyvän kilpailemaan keskitasoa heikomman lypsylehmän kanssa edellyttäen, että tavoitteena on saada jalostetuksi karkeat rehut markkinakelpoisiksi tuotteiksi. Lammas ja 1.5 - 2 vuotias lihanauta maksavat suoritettujen laskelmien mukaan suunnilleen saman suuruisen korvaushinnan karkeista rehuista.

Tässä tutkimuksessa esitetyt laskelmat perustuvat sekä lammastalouden että naudanlihan osalta pieneen tutkimusaineistoon. Kun laskelmien perusaineistoon sisältyy huomattava hajonta, muodostuvat tulokset epävarmoiksi. Tarvittaisiin lisätutkimuksia sekä lammastalouden että naudanlihan tuotannon alalta. Erityisen mielenkiintoisia olisivat käytännön viljelmiltä saatavat sekä lammas- että lihakarjatalouden kannattavuutta koskevat tutkimukset.

\section{KIRJALLISUUTTA}

Andersson, E. 1960. Lönar det sig att hålla får. Hush.sällsk.förb. Småskrift. 42: 1-15.

Gustafsson, T. och SJöberg, K. E. 1966. Data om får med ekonomiska beräkningar. Aktuellt från lantbr. högsk. 88: 1-106. $32 \mathrm{~s}$.

Huokuna, E. 1964. The effect of frequency and height of cutting on cocksfoot swards. Ann. Agric. Fenn. 3. Suppl. 4: $1-83$.

InkovaARA, N. 1964. Lammas. Maanviljelijän tietokirja 2: 611-654. 
Johnsson, H., Myrehed, I. och Renborg, U. 1960. Fårskötselns ekonomi. Medd. från jordr.utr.inst. 2-60: 1-131.

Lammastoimikunnan mietintö II. Komiteamietintö 1965: B 59.

Lampaiden tuotannontarkkailu 1962 ja 1967. Lammastalous 2/1962 ja 4/1967.

LARPES, E. 1963. Mullivasikoiden kasvatuskoe vuosina 1960 - 62. Maatal. ja koetoim. XVII: 263-278.

—»- 1965. Kevätvasikoista ruohovasikoiksi. Koetoim. ja käytäntö 22, 6: 17, 19 -20.

—— 1966. Koetuloksia härkien kasvatuksesta. Sama. 23, 7: 27-28.

—— 1968 a. Eläinrasva ja kuivaruokinta vasikoiden kasvatuksessa. Sama. 25, 1: 2-3.

—— 1968 b. Koetuloksia nuoren naudan kasvatuksesta. Sama. 25, 1: 4.

MajjalA, K. 1967. Causes of variation in litter size of Finn-sheep ewes. S. maat.tiet. seur. julk. 109, 1-2: $136-143$.

Nedkvitne, J. 1965. Hog lammeadrått hjå søyene krev god föring och stor omtanke. Norges landbr. høgsk.inst. for husdj. ern. og for. laere. Saertr. 295.

- - 1966. Oppal av søyer. Sama. Saertr. 301.

Nielsen, J. 1960. Forsøg med får. Ber. fra forsøgslab. 318.

Tuottajahintatilastoa 1966/67, 1967/68. Maatal. kuukausikatsaus. Maatal.hall. tilastot. 8/1968.

Tutkimuksia S. maatal. kannattavuudesta tilivuosina 1960/61-1963/64. Maatal. tal.tutkim.lait. julk. $4-7$.

\title{
SUMMARY
}

\section{ON THE PROFITABILITY OF SHEEP HUSBANDRY ON MALMINKARTANO FARM}

\author{
ViLjo RyYnänen
}

\section{Department of Agricultural Economics, University of Helsinki}

An experiment in the economics of sheep husbandry was started at Malminkartano experimental farm, University of Helsinki in 1962. One of the main aims was to study the economic and technical possibilities of sheep husbandry in conditions in which sheep rearing is a subsidiary job on the farm. Fodder consumption during the winter feeding period and the technique of pasturage in intensively cultivated pastures were also studied.

The experimental farm has on old cattle shed which was used as a sheep shed to start with. A sheep shed of 112 sq.m. was built in 1964. The walls and ceiling are surfaced with sawn board. Heat insulation is provided by a $30 \mathrm{~cm}$ layer of straw in the walls and ceiling. The floor is of gravel with straw spread for bedding. Manure is removed once a year. The total cost of building the sheep shed was 3000 marks, which worked out at 60 marks per ewe. The estimated life of the sheep shed is $15-20$ years.

Twenty sheep of Finnish native breed were bought for the farm in 1962. This stock was increased to a flock of about 50 ewes in 1966.

The fodder used by the sheep and the distribution by type of fodder are shown in Table 1 . The amount of pasture forage was estimated in accordance with the norms. The average fodder consumption per ewe including 5 months old lambs (average 1.8 lambs) as a three years' mean was 440 fodder units.

The ewes lambed for the first time at the age of 12 months. The average number of lambs born to all the ewes can be seen from Tables 2 and 3. The number of lambs born to ewes that lambed at an age of over two years was 2.7, and the number of five months old lambs was 2.2 per ewe.

Fifty five per cent of the lambs were slaughtered. The lambs of the best ewes were used for breeding on the farm or sold as breeding sheep. The lambs were slaughtered at the age of $41 / 2$ months. The carcass weight according to slaughter-house records was $9.7 \mathrm{~kg}$. The meat output per ewe was $17.5 \mathrm{~kg}$ (Table 4).

Wool production in 1963-1967 was an average of $2.5 \mathrm{~kg}$ per ewe. Lambs left for breeding purposes yielded $1.0 \mathrm{~kg}$ wool at the age of six months (Table 5).

The gross return from sheep husbandry at 1967 prices is given in Table 6. The gross return per ewe varied considerably. The main factors affecting this were the number of lambs used for breeding on the farm and the age and number of lambs sold for breeding. 
The average expenditure on sheep husbandry at the experimental farm is given in Table 7. It also shows the net return of sheep husbandry. Table 8 gives the calculated processing price per fodder unit for roughage (hay, silage, pasture, straw). This was calculated by deducting from the total return all production costs other than the price of roughage. The remainder was divided by the number of fodder units of roughage. Table 9 presents the processing price when the number of lambs per ewe varies. The gross margin of sheep husbandry per ewe is calculated in Table 10. The gross margin here covers labour costs, depreciation of buildings and interest on invested capital. Table 11 gives for comparison the processing price calculations for roughage in beef and milk production. The calculations for meat production were performed on the assumption that all the fodder consumed by sheep on an experimental farm went into meat production, that the livestock was kept in the same buildings as the sheep, and that the total labour input was equal for both productions. The figures on fodder consumption were obtained from experiments conducted by The Livestock Husbandry Research Institute (LARPES 1963-1968). The model calculation for a dairy cow is based on the average costs.

The results obtained from the experimental farm and the calculations made show that milk production and the raising of calves (fed mostly on roughage) is more profitable than sheep husbandry. When the milk production of dairy cattle is under average, sheep husbandry can compete with dairy cattle as regards processing price for roughage. The calculations indicate that a sheep and a yearling or a heifer for beef production yield roughly the same processing price for the roughage they consume. 